Correction

\title{
Correction: Deuchar, M.; Stammers, J.R. English-Origin Verbs in Welsh: Adjudicating between Two Theoretical Approaches. Languages 2016, 1, 7
}

\author{
Margaret Deuchar ${ }^{1,2, *}$ and Jonathan R. Stammers ${ }^{1}$ \\ 1 Centre for Research on Bilingualism, Bangor University, College Rd., Bangor, Gwynedd LL57 2DG, UK; \\ jon.stammers@gmail.com \\ 2 Department of Theoretical and Applied Linguistics, University of Cambridge, 9 West Rd., \\ Cambridge CB3 9DP, UK \\ * Correspondence: m.deuchar@gmail.com
}

Received: 7 June 2018; Accepted: 7 June 2018; Published: 8 June 2018

The authors wish to make the following correction to the paper by Deuchar and Stammers [1]. Table 1 (p. 7):

Table 1. Definitions vs. hypotheses: Poplack and Meechan vs. Myers-Scotton.

\begin{tabular}{ccc}
\hline Lone Other-Language Items & Definitions of Borrowings/Switches & Hypotheses \\
\hline $\begin{array}{c}\text { Poplack and Meechan } \\
\text { Myers-Scotton }\end{array}$ & $\begin{array}{c}\text { Linguistically integrated/not linguistically } \\
\text { integrated }\end{array}$ \\
\cline { 2 - 2 } & More frequent/less frequent & Borrowings more frequent than switches \\
\cline { 2 - 2 } & & Borrowings less integrated than switches \\
\hline
\end{tabular}

should be replaced by:

Table 2. Definitions vs. hypotheses: Poplack and Meechan [2] vs. Myers-Scotton [3].

\begin{tabular}{ccc}
\hline Lone Other-Language Items & Definitions of Borrowings/Switches & Hypotheses \\
\hline $\begin{array}{c}\text { Poplack and Meechan } \\
\text { Myers-Scotton }\end{array}$ & $\begin{array}{c}\text { Linguistically integrated/not } \\
\text { linguistically integrated } \\
\text { More frequent/less frequent }\end{array}$ & Borrowings more frequent than switches \\
\hline
\end{tabular}

These changes have no material impact on the conclusions of the paper. The authors would like to apologize for any inconvenience caused to the readers by these changes.

\section{References}

1. Deuchar, M.; Stammers, J.R. English-Origin Verbs in Welsh: Adjudicating between Two Theoretical Approaches. Languages 2016, 1, 7. [CrossRef]

2. Myers-Scotton, C. Duelling Languages: Grammatical Structure in Codeswitching; Clarendon Press: Oxford, UK, 1993.

3. Poplack, S.; Meechan, M. Introduction: How Languages Fit Together in Codemixing. Int. J. Biling. 1998, 2, 127-138. [CrossRef]

(C) 2018 by the authors. Licensee MDPI, Basel, Switzerland. This article is an open access article distributed under the terms and conditions of the Creative Commons Attribution (CC BY) license (http:/ / creativecommons.org/licenses/by/4.0/). 